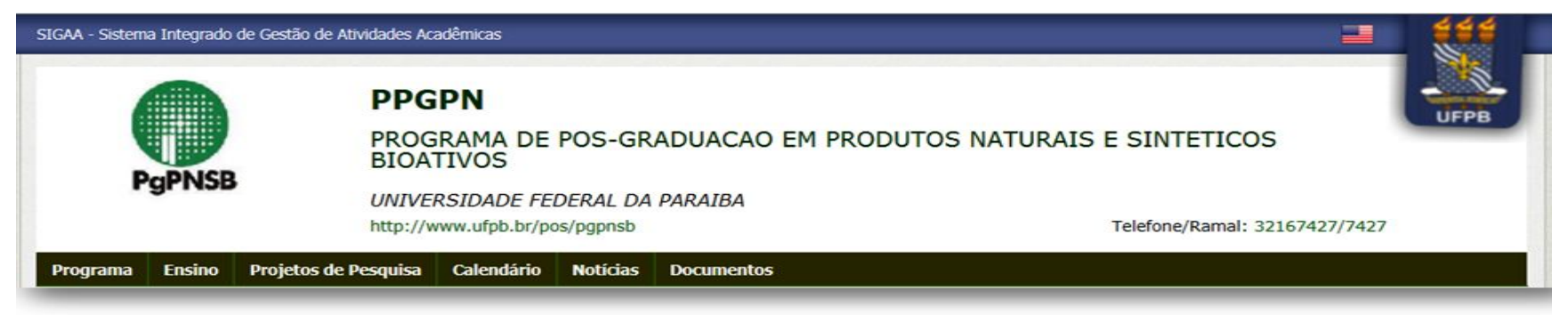

\title{
SciForum
}

MOL2NET

\section{Use of Hypericum perforatum (HP) for the treatment of psychiatric disorders: moderate to severe unipolar depression}

\begin{abstract}
Claudia Kowalesky Silva ${ }^{1, *}$, Raiza Santos de Góis ${ }^{2}$, Lucas Miguel Lima do Amaral ${ }^{3}$, Gabriela Palitot Lourenço ${ }^{4}$, Vanessa de Melo Cavalcanti Dantas ${ }^{5}$, Lúcio Roberto Cançado Castellano ${ }^{6}$, Paulo Rogério Ferreti Bonan ${ }^{7}$, and Daniela Bomfim de Barros ${ }^{8}$
\end{abstract}

1*FPB - Faculdade Internacional da Paraíba, João Pessoa - PB/Brasil; E-Mail: claudiakowalesky@hotmail.com Tel.: +55 (83) 99852-3042

${ }^{2}$ FPB - Faculdade Internacional da Paraíba, João Pessoa - PB/Brasil;

${ }^{3}$ FPB - Faculdade Internacional da Paraíba, João Pessoa - PB/Brasil;

${ }^{4}$ FPB - Faculdade Internacional da Paraíba, João Pessoa - PB/Brasil;

${ }^{5}$ FPB - Faculdade Internacional da Paraíba, João Pessoa - PB/Brasil;

${ }^{6}$ UFPB - Universidade Federal da Paraíba, João Pessoa - PB/Brasil;

${ }^{7}$ UFPB - Universidade Federal da Paraíba, João Pessoa - PB/Brasil.

${ }^{8}$ FPB - Faculdade Internacional da Paraíba, João Pessoa - PB/Brasil;

Received: / Accepted: / Published:

\begin{abstract}
:
In recent decades there has been a constant growth in the search for alternative treatments and in the therapeutic use of natural products, which combine efficacy and reduce of adverse effects. Phytotherapy stands out in the treatment of psychiatric disorders because its efficacy is proven through herbal preparations, emphasizing Hypericum perforatum (HP). Latter is a plant of the family Hypericaceae, perennial herbaceous from temperate regions of Europe, Asia and Africa, and has been used for centuries in traditional medicine to treat and prevent various diseases due to its nefroprotective effects, antioxidant, antifungal, anxiolytic, antidepressants, antiviral, healing, and help with sleep disorders. At present, it is a great source of studies for the scientific community, as a result of the large amount of secondary metabolites and bioactive compounds present in it. Among the pharmacological activities that the plant has, the antidepressant action owing to the variety of bioactive compounds, hypericin (responsible for the inhibition of the enzyme monoamine oxidase - MAO), hyperforin (capable of inhibiting the reuptake of serotonin, dopamine, noradrenaline, GABA and L-glutamate) and flavonoids the main responsible for this action, which also favor the reduction of the degradation and increase the sensitization ofneurochemical substances, as well as the enhance of the binding to several receptors, also demonstrating greater effectiveness when compared to the placebo effect.
\end{abstract}

Keywords: Phytotherapy; Alternative Medicine; Bioactive Compounds. 


\section{Introduction}

In recent years there has been a constant growth in the search for alternative treatments and in the therapeutic use of natural products, since they are allied with reduced adverse effects and easy access (RUSSO et al., 2013, ALVES et al., 2014).

Among all the purposes of its use, its role in the treatment of psychiatric disorders is highlighted, since its efficacy is proven through phytotherapeutic preparations (SARRIS, J. 2018).

Hypericum perforatum (HP) is a plant that comes from the Hypericaceae family, being

\section{Results and Discussion}

Depression, also called Depressive Disorder, Major Depression or Unipolar Depression, is a disease defined by the World Health Organization as the fourth major cause of impact among all diseases in the world, being characterized by persistent mood and/or behavior changes for at least two weeks (BARBIERO et al., 2008). HP presents itself as one of the few natural antidepressants, making it an effective alternative to its treatment (ALVES, et al., 2014).

Its antidepressant mechanism of action is considered to involve non-selective inhibition of neuronal reuptake of serotonin, dopamine, noradrenaline, gamma-aminobutyric acid (GABA) and L-glutamate. In addition, it promotes the increase of its connections to several receptors, and the main components responsible for this effect are hypericin,

\section{Materials and Methods}

A literature review was carried out to analyze the most recent data and research on the a perennial herbaceous originated in temperate regions of Europe, Asia and Africa (ISTIKOGLOU; MAVREAS; GEROULANOS, 2010).

This plant has antidepressant properties due to its action equivalent to amitriptyline, fluoxetine, sertraline and maprotiline, presenting as a great source for the scientific community (ISTIKOGLOU; MAVREAS; GEROULANOS, 2010; ALVES et al., 2014; OLIVEIRA et al. 2016). In this way, the objective of this work is to evaluate the effectiveness of the plant Hypericum perforatum in the treatment of moderate and severe depressions.

hyperforin, and various flavonoids (OLIVEIRA et al., 2016; FORSDIKE; PIROTTA, 2017; SARRIS, 2018).

Studies have shown that these same components are also responsible for the inhibition of monoamine oxidase (MAO) through the use of hypericin (VOLLMER, J. J .; ROSENSON, J. 2004). Other related effects are suppression of interleukin-6, which is related to depression as it modulates the release of cortisol (THIEDE; WALPER, 1994; RUSSO et al. 2013).

Although the use of HP is considered safe (doses above $11.25 \mathrm{mg}$ total hypericin), gastrointestinal complaints, fatigue, dizziness, allergic reactions and photosensitivity are occasionally reported (BORELLI; IZZO, 2009).

subject, in English and Portuguese, in the databases WILEY, FRONTIERS, ResearchGate, 
PubMed, and SCIELO, in order to obtain a theoretical basis. The descriptors used were:

"Phytotherapy",

"Bioactive
"Alternative treatment", compounds".

\section{Conclusions}

The use of Hypericum perforatum is historical and of proven efficacy, however, few studies are still observed regarding its active compounds and possible uses. The low incidence of side effects combined with the low cost of HP show a viable and safe therapeutic alternative when used alone in comparison to synthetic antidepressants.

\section{Acknowledgments}

I am grateful to my advisors and to the LACEC research group, in which I take part in providing me with so many opportunities and knowledge sharing.

\section{Conflicts of Interest}

The author declares there is no conflict of interest.

\section{References and Notes}

1. Alves, A. C. S.; Moraes, D. C., Aspectos botânicos, químicos, farmacológicos e terapêuticos do Hypericum perforatum. L.,Rev. Bras. Pl. Med., 2014, v.16, 593-606, doi: 10.1590/1983084X/12_149 Available online:http://www.scielo.br/scielo.php?pid=S151605722014000300017\&script=sci_abstract\&tlng=pt (accessed on 08/09/2018)

2. Barbiero, J.; Delazzeri, K. A. O., A depressão como mal do século XXI, 2008. Avaliable online: http://artigos.netsaber.com.br/resumo_artigo_3693/artigo_sobre_a-depressao-como-o-mal-doseculo-xxi (accessed on 08/09/2018)

3. Borrelli, F.; Izzo, A. A. Herb-Drug Interactions with St John's Wort (Hypericumperforatum): an Update on Clinical Observations. The AAPS Journal, 2009, v.11, 710-727

4. Diniz, A. C., Astarita, L., Alteração dos metabólitos secundários em plantas de Hypericum perforatum L. (Hypericaceae) submetidas à secagem e ao congelamento.Acta bot. bras., 2007, v.21, 443-450

5. Forsdike, K.; Pirotta, M., St John's wort for depression: scoping review about perceptions and use by general practitioners in clinical practice. Journal of Pharmacy and Pharmacology, 2017, doi: 10.1111/jphp.12775 Avaliable Online: sci-hub.tw/10.1111/jphp.12775(accessed on 08/09/2018)

6. Istikoglou, C. I.; Mavreas, V., History and therapeutic properties of Hypericum Perforatum from antiquity until today. Psychiatriki, 2010, v.21, PMID: 21914616 Avaliable online: https://www.ncbi.nlm.nih.gov/pubmed/21914616 (accessed on 08/09/2018)

7. Oliveira A. I. et al. Neuroprotective Activity of Hypericum perforatum and Its Major Components. Front. Plant Sci., 2006, v.7, doi: 10.3389/fpls.2016.01004 Avaliable online: https://www.frontiersin.org/articles/10.3389/fpls.2016.01004/full (accessed on 08/09/2018)

8. Sarris, J., Herbal medicines in the treatment of psychiatric disorders: 10-year updated review, Phytotherapy Research, 2018, v.32, 1147-1162

9. Thiede H. M.; Walper, A. Inhibition of MAO and COMT by Hypericum Extracts and Hypericin. Journal of Geriatric Psychiatry and Neurology, 1994, v.7, 54-56

10. Vollmer, J. J.; Rosenson, J., Chemistry of St. John's Wort: Hypericin and Hyperforin,J. Chem. Educ., 2004, v.81, 1450-1456. 